\title{
Climatic and atmospheric circulation pattern variability from ice-core isotope/geochemistry records (Altai, Tien Shan and Tibet)
}

\author{
Vladimir B. AIZEN, ${ }^{1}$ Elena M. AIZEN, ${ }^{1}$ Daniel R. JOSWIAK, ${ }^{1}$ Koji FUJITA, ${ }^{2}$ \\ Nozomu TAKEUCHI, ${ }^{3}$ Stanislav A. NIKITIN ${ }^{4}$ \\ ${ }^{1}$ College of Science, University of Idaho, PO Box 443025, Moscow, ID 83844, USA \\ E-mail: aizen@uidaho.edu \\ ${ }^{2}$ Hydrospheric Atmospheric Research Center, Nagoya University, Nagoya 464-8601, Japan \\ ${ }^{3}$ Research Institute for Humanity and Nature, Takashima-cho 335, Kyoto 602-0878, Japan \\ ${ }^{4}$ Department of Glacio-Climatology, Tomsk State University, 634050 Tomsk, Russia
}

\begin{abstract}
Several firn/ice cores were recovered from the Siberian Altai (Belukha plateau), central Tien Shan (Inilchek glacier) and the Tibetan Plateau (Zuoqiupu glacier, Bomi) from 1998 to 2003. The comparison analyses of stable-isotope/geochemistry records obtained from these firn/ice cores identified the physical links controlling the climate-related signals at the seasonal-scale variability. The core data related to physical stratigraphy, meteorology and synoptic atmospheric dynamics were the basis for calibration, validation and clustering of the relationships between the firn-/ice-core isotope/ geochemistry and snow accumulation, air temperature and precipitation origin. The mean annual accumulation (in water equivalent) was $106 \mathrm{~g} \mathrm{~cm}^{-2} \mathrm{a}^{-1}$ at Inilchek glacier, $69 \mathrm{~g} \mathrm{~cm}^{-2} \mathrm{a}^{-1}$ at Belukha and $196 \mathrm{~g} \mathrm{~cm}^{-2} \mathrm{a}^{-1}$ at Zuoqiupu. The slopes in regression lines between the $\delta^{18} \mathrm{O}$ ice-core records and air temperature were found to be positive for the Tien Shan and Altai glaciers and negative for southeastern Tibet, where heavy amounts of isotopically depleted precipitation occur during summer monsoons. The technique of coupling synoptic climatology and meteorological data with $\delta^{18} \mathrm{O}$ and d-excess in firn-core records was developed to determine climate-related signals and to identify the origin of moisture. In Altai, two-thirds of accumulation from 1984 to 2001 was formed from oceanic precipitation, and the rest of the precipitation was recycled over Aral-Caspian sources. In the Tien Shan, 87\% of snow accumulation forms by precipitation originating from the Aral-Caspian closed basin, the eastern Mediterranean and Black Seas, and 13\% from the North Atlantic.
\end{abstract}

\section{INTRODUCTION}

Well-dated, high-resolution ice-core records from middleand low-latitude glaciers provide the opportunity to extend the climate and environmental record back in time using highly robust, annually to seasonally resolved, multivariate, instrumentally calibrated time series. These records, developed through the isotope, geochemical and physical analysis of ice cores, provide information that can be directly linked to, for example, changes in atmospheric circulation (Taylor and others, 1993; Mayewski and others, 1994, 1997; O'Brien and others, 1995; Aizen and others, 1996, 2004, 2005), temperature (Yao and Thompson 1992; Jouzel and others, 1997; Petit and others, 1999; Yao and others, 1999; Thompson and others, 2003) and continental dust sources (Basile and others, 1997; Biscaye and others, 1997). An important topic of investigation is to understand the main pathways of the global water cycle, i.e. how far the influence of the Atlantic/Pacific extends toward the east/ west, what is the influence of monsoonal moisture and what is the role of the world's largest closed drainage basin in the global hydrological cycle. Climatic high-resolution records recovered from ice cores obtained in central Asia between 1999 and 2003 at Inilchek glacier, Tien Shan, at the west Belukha plateau, Siberian Altai, and at Zuoqiupu glacier, Bomi glaciation, southeast Tibet, (Fig. 1; Table 1) provide data that complement records already developed from other Asian mountains (e.g. Sentik, Dunde, Guliya, Xixabangma and Qomolangma) (Thompson and others, 1989, 1997, 2000; Kang and others, 2000; Qin and others, 2000).
This research will identify, calibrate and validate the physical links controlling the climate and atmospheric dynamic signals preserved in snow/firn/ice cores from alpine regions of Asia, i.e. Siberian Altai, central Tien Shan and southeastern Tibet, using stable-isotope, geochemical and dust particle analyses. By coupling the snow/firn/ice-core records with the precipitation-origin time series through analysis of synoptic-scale atmospheric dynamics, we will update the evaluation of the contribution of water vapor, associated with external and internal water cycles, to snow accumulation over the great Asiatic mountains. Furthermore, this allows examination of forcing mechanisms, interactions and feedbacks.

\section{STUDY REGIONS}

\subsection{Long-term data}

For determination of isotope-air-temperature relationships, seasonal/monthly calibration of annual accumulation layers in snow/firn/ice-core records was used in conjunction with long-term monthly-averaged meteorological data from stations within $10-150 \mathrm{~km}$ of the drill sites and with data from established automated weather stations in the immediate vicinity of the drilling sites. Data from these stations have the highest correlation with air temperature and precipitation time series at the studied glaciers. The longterm average monthly air precipitation and temperature for the period 1990-2000 at the altitudes of the drilling sites (Fig. 2a and b) were calculated from linear extrapolation of 


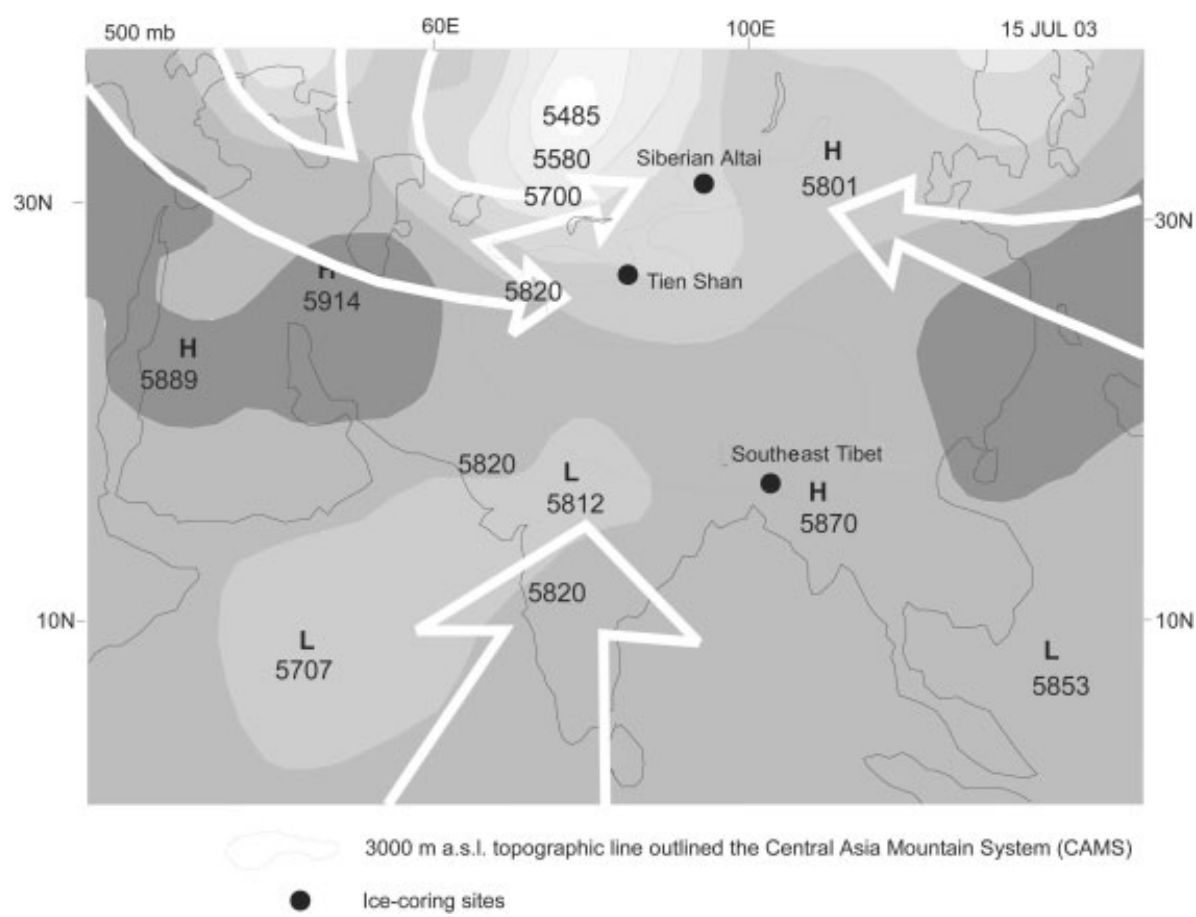

Fig. 1. Study locations at the northern and southern periphery of the Asian mountain system, with the main trajectories of air masses that bring moisture to them.

air temperatures and precipitation at referenced stations with mean altitudinal gradients (Table 2).

To describe atmospheric circulation patterns that influence regional precipitation regimes at seasonal timescales, we used monthly data on the frequency of synoptic patterns observed over the southwestern Siberian Altai and the central Tien Shan, developed by Bugaev and others (1957), Popova (1972), Narojniy and others (1993) and Subbotina (1995) and partially presented in the Central Asia Data Base which is completed and maintained by the authors at the University of Idaho (UI). A brief description of synoptic pattern classifications over Siberia and central Asia is presented in Aizen and others (2004, 2005). The prevailing synoptic patterns associated with precipitation are listed in Table 3.

\subsection{Climatic regime}

All the study locations exhibit maximum temperature and precipitation during the summer months. Two of these, Tien Shan in central Asia and Altai in the Siberian mountains, are distinguished by a continental climate with significant annual air-temperature variation, up to $20^{\circ} \mathrm{C}$ at the Tien Shan and $16^{\circ} \mathrm{C}$ at the Altai drilling sites (Fig. 2b). These glaciers store records of the advection of fresh water transferred from the Atlantic, Pacific and Arctic Oceans (Aizen and others, 2004, 2005) (Fig. 1). The firn records from the Tien Shan and Altai glaciers can be directly associated with one of the world's largest internal water systems, i.e. the Aral-Caspian and Tarim.

The third studied region is the Bomi glacial massif located in the Hengduan range of southeastern Tibet, along the windward slope of the southwest monsoon. Annual airtemperature variation is significantly less $\left(13^{\circ} \mathrm{C}\right)$ in southeast Tibet than at the central Asian drilling sites (Fig. 2b). Under the influence of the monsoon, the heaviest amounts of precipitation occur at the Tibetan study location (Fig. 2a).

\section{MEASUREMENTS, PROCESSING AND ANALYSES}

\subsection{Field sampling and measurements}

The firn-/ice-core, snow-pit and fresh-snow samples obtained during field seasons 1998-2003 were collected using established sampling techniques for isotope/geochemical analysis (Kreutz and others, 2001, 2003; Aizen and others, 2004, 2005). Core dimensions and weight were measured,

Table 1. Brief description of ice cores and their records that were used in current research

\begin{tabular}{|c|c|c|c|c|c|c|c|c|}
\hline \multirow[t]{3}{*}{ Region } & \multicolumn{4}{|c|}{ Obtained ice cores } & \multicolumn{4}{|c|}{ Period of years from available records } \\
\hline & \multicolumn{2}{|c|}{ Shallow } & \multicolumn{2}{|r|}{ Deep } & \multirow[t]{2}{*}{$\delta^{18} \mathrm{O}$} & \multirow[t]{2}{*}{$\delta \mathrm{D}$} & \multirow[t]{2}{*}{ Major ions } & \multirow[t]{2}{*}{ Dust particles } \\
\hline & $\begin{array}{c}\text { Depth } \\
\text { m }\end{array}$ & $\begin{array}{l}\text { Period } \\
\text { years }\end{array}$ & $\begin{array}{c}\text { Depth } \\
\text { m }\end{array}$ & Approx. period & & & & \\
\hline Siberian Altai & 21 & 17 & 175 & $1500-2000$ & 17 & 17 & 17 & 17 \\
\hline Central Tien Shan & 16 & 8 & 165 & $300-500$ & $5-8$ & 5 & 8 & \\
\hline Southeast Tibet & 16 & $4-5$ & & & $4-5$ & & $4-5$ & \\
\hline
\end{tabular}



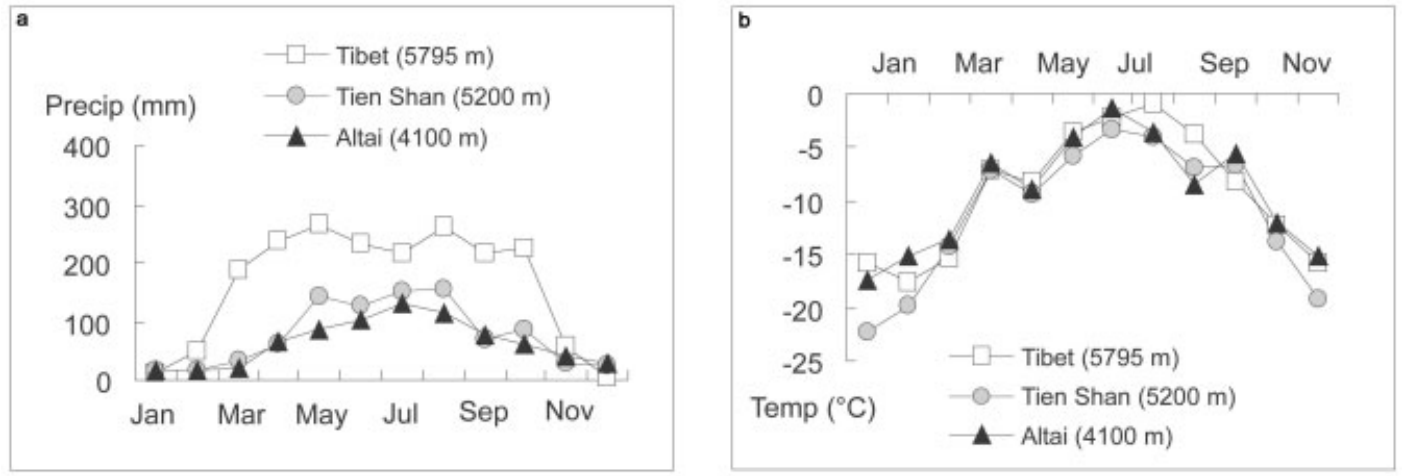

Fig. 2. Average monthly precipitation (a) and air temperatures (b) corrected with the local seasonal lapse rates to drill-site elevations (Siberian Altai, $4115 \mathrm{~m}$ ).

followed by detailed description of the physical stratigraphy using a light table and photographs of each core section. The seasonal layers in the Tien Shan and Altai were differentiated from the others by their crystal structure (Fig. 3) (Aizen and others, 2004, 2005). Each drill run was photographed, packed into pre-cleaned plastic packets and shipped frozen from the drilling sites to UI and University of Maine (UM), USA, where they are currently stored.

The drilling sites were identified as suitable locations for recovery of firn/ice cores and subsequent development of climatic records. Summer air temperatures (Fig. 2a), snow-pit and firn-core temperatures (Fig. 4) and stratigraphy profiles (Fig. 3) revealed negligible snowmelt and the absence of meltwater percolation, which redistributes isotopic signals.

The stratigraphic profiles from the Tien Shan and Altai firn/ ice cores show drier, colder depositional environments representing the cold recrystallization zones of glacier accumulation areas with less annual accumulation at lower altitudes compared to southeast Tibet (Figs 2-4). Temperature profiles show decreasing temperatures with depth, and although the temperature profile at the southeast Tibetan site shows increasing temperatures in the first $1 \mathrm{~m}$ before decreasing with depth, the entire profile is below $0^{\circ} \mathrm{C}$. Snowpit density ranges are similar in central Asia $\left(0.22 \mathrm{~g} \mathrm{~cm}^{-3}\right.$ at the surface to $0.49 \mathrm{~g} \mathrm{~cm}^{-3}$ at $2 \mathrm{~m}$ snow depth) and southeastern Tibet $\left(0.21-0.55 \mathrm{~g} \mathrm{~cm}^{-3}\right)$, although density at the latter site increases more rapidly within the first $3 \mathrm{~m}$ (Fig. 3). A warmer, wetter depositional environment at the southeast Tibetan site, with precipitation closer to $0^{\circ} \mathrm{C}$, results in the distinctive feature of occasional thin $(1-3 \mathrm{~mm})$ wind/solar radiative crusts in the stratigraphic profiles (Fig. 3).

In the remote field locations, Grant Instruments and Campbell Scientific (Logan, UT) automated weather stations and data loggers were used to record hourly measurements of air and ice temperatures. An automatic snow-depth gauge (KADEC-SNOW, KONA system) was installed on the Altai glacier drilling site in July 2001, with sensor detection of snow or open air by photo diodes at an interval of $1 \mathrm{~cm}$. Two daily measurements, one in the morning and one in the evening, recorded the snow surface level for 2 months.

\subsection{Stable-isotope processing}

Each $3-5 \mathrm{~cm}$ of the upper part of the snow/firn core, as well as samples from five snow pits, and fresh snow, were analyzed for $\delta^{18} \mathrm{O}$ and $\delta \mathrm{D}$ in collaboration with the UI, UM, University of New Hampshire, USA, and the Japanese National Institute of Polar Research, Tokyo. The analytical precision for measurements of oxygen and deuterium isotopic ratios was $\pm 0.05 \%$ and $\pm 0.5 \%$ respectively in each laboratory. The technique of snow/firn-core stable-isotope processing and analysis has been described by Kreutz and others (2001).

\section{DATA ANALYSIS TECHNIQUE}

\subsection{Ice-core/snow-pit dating}

Ice-core dating was preliminarily assigned through counting of annual layers based on detailed inspection of the visible stratigraphy (Fig. 3). The established ice-core chronology

Table 2. Gradient ranges established from monthly (subscript $\mathrm{m}$ ) or annual (subscript a) station data. $H$ is elevation and $\gamma(T)$ and $\gamma(P)$ are airtemperature and precipitation gradients

\begin{tabular}{|c|c|c|c|c|c|c|c|c|}
\hline Location & Station & $\begin{array}{l}H_{\text {station }} \\
\text { ma.s.l. }\end{array}$ & Drilling glacier & $\begin{array}{c}H_{\text {drill site }} \\
\text { ma.s.l. }\end{array}$ & $\begin{array}{c}\gamma_{\mathrm{m}}(P) \\
\mathrm{mm}(100 \mathrm{~m})^{-1}\end{array}$ & $\begin{array}{c}\gamma_{\mathrm{a}}(P) \\
\mathrm{mm}(100 \mathrm{~m})^{-1}\end{array}$ & $\begin{array}{c}\gamma_{\mathrm{m}}(T) \\
{ }^{\circ} \mathrm{C}(100 \mathrm{~m})^{-1}\end{array}$ & Source \\
\hline \multirow[t]{2}{*}{ Siberian Altai } & Kara-Turek & 2600 & $\begin{array}{l}\text { Belucha } \\
\left(49^{\circ} 48^{\prime} N, 86^{\circ} 32^{\prime} E\right)\end{array}$ & 4110 & $0.18-2.2$ & & -0.06 to -0.46 & Aizen and others (2005) \\
\hline & Akkem & 2045 & & 4110 & $0.18-2.2$ & 7 & -0.06 to -0.46 & \\
\hline Central Tien Shan & Tien Shan & 3614 & $\begin{array}{l}\text { Inylchek } \\
\left(42^{\circ} 13^{\prime} \mathrm{N}, 80^{\circ} 12^{\prime} \mathrm{E}\right)\end{array}$ & 5200 & & 63 & -0.05 to -0.54 & $\begin{array}{l}\text { Aizen and Aizen (1997); } \\
\text { Aizen and others (2004) }\end{array}$ \\
\hline Southeast Tibet & $\begin{array}{l}\text { Zuoqiupu } \\
\text { Bomi } \\
\text { Chayu } \\
\text { Linzhi }\end{array}$ & $\begin{array}{l}5200 \\
2736 \\
2328 \\
2992\end{array}$ & $\begin{array}{l}\text { Zuoqiupu } \\
\left(29^{\circ} 30^{\prime} \mathrm{N}, 97^{\circ} 00^{\prime} \mathrm{E}\right)\end{array}$ & 5795 & -6.7 to 12 & $31-34$ & -0.05 to -0.56 & Current research \\
\hline
\end{tabular}


a

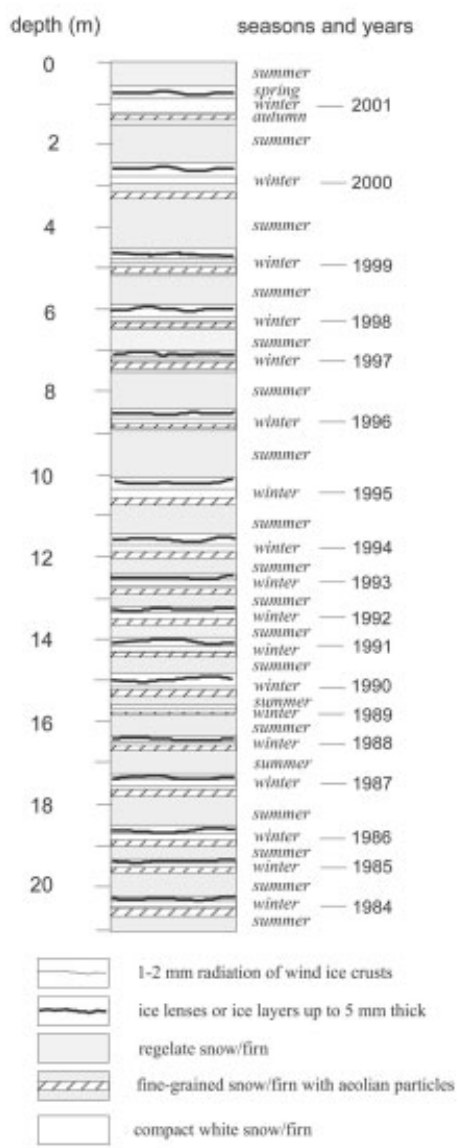

b Depth (m) Tien Shan
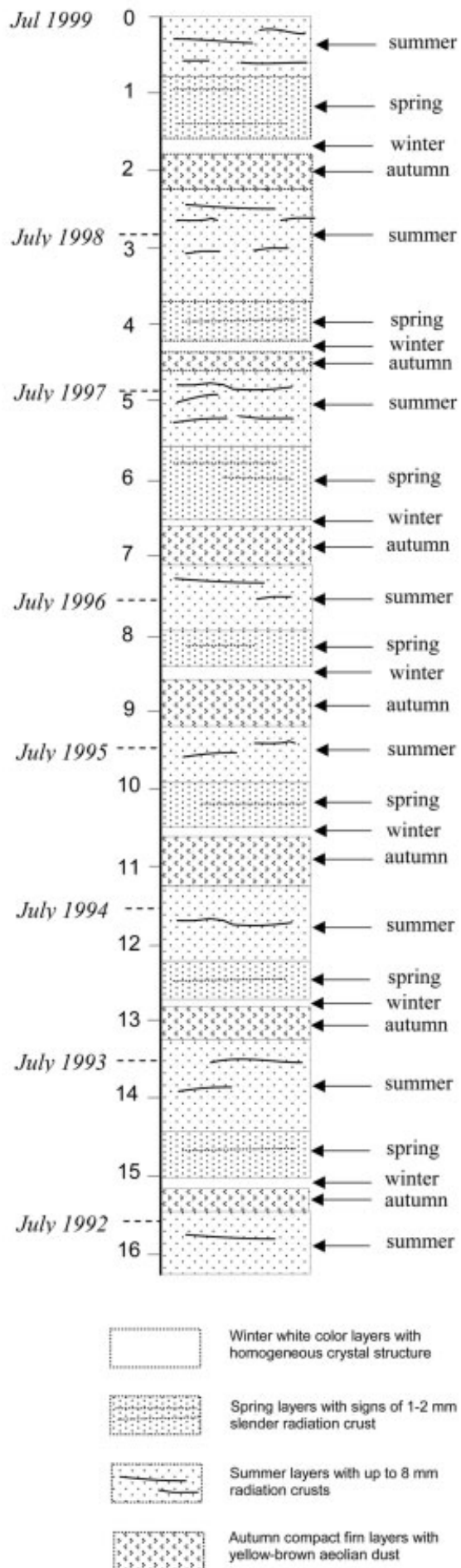

C Tien Shan

Snow pit No. 2 at drilling site, $5100 \mathrm{~m}$
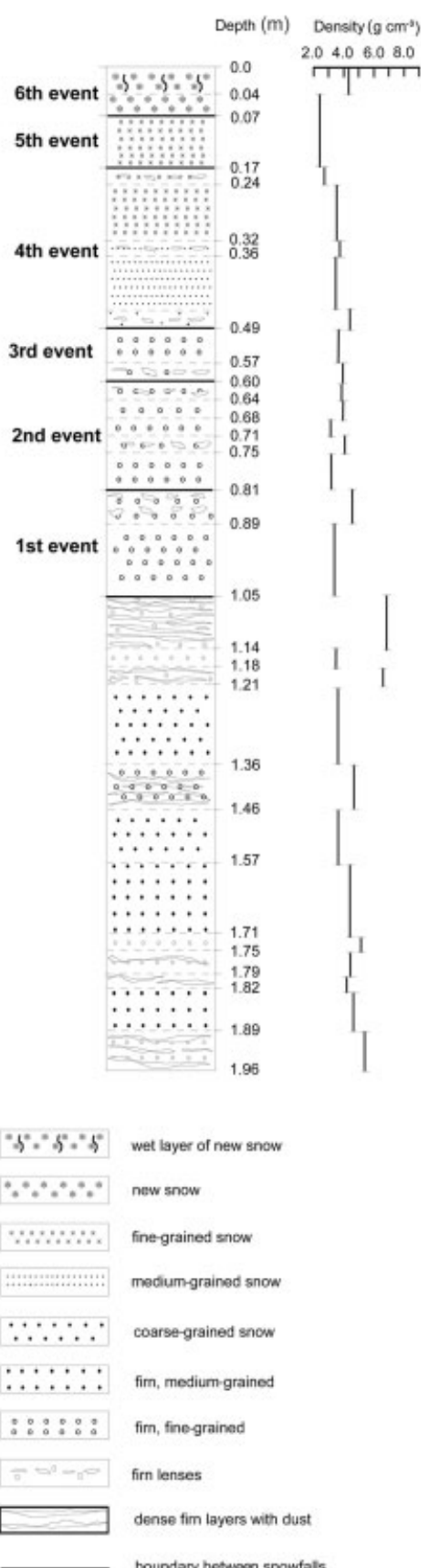

Fig. 3. Snow/firn physical stratigraphy with seasonal- and annual-layer identification: (a) Siberian Altai $21 \mathrm{~m}$ snow/firn core recovered from the west Belukha plateau; (b) Tien Shan $16 \mathrm{~m}$ firn/ice crevasse located at the edge of the Inilchek glacier accumulation area; and (c) snow stratigraphy, snow density and layers of six precipitation events in snow pit on Inilchek glacier (Aizen and others, 2004).

was further refined by counting annual layers in stable isotopes (Fig. 5), which show well-preserved annual variation profiles (Kreutz and others, 2001; Aizen and others, $2004,2005)$. The mean accumulation rate obtained from the shallow Altai ice cores agrees with the rate validated through tritium and ${ }^{210} \mathrm{~Pb}$ records by Olivier and others (2003). Annual net accumulation at field sites amounted to $690 \mathrm{~mm}$ at the Belukha, $1060 \mathrm{~mm}$ at the Inilchek and $1960 \mathrm{~mm}$ at the Zuoqiupu drilling sites.
To determine the seasonal and monthly accumulation and corresponding seasonal and monthly isotope means, the normalization technique (Barlow and others, 1993; Shuman and others, 1995; Yao and others, 1999; Aizen and others, 2004) was applied. Annual accumulation at the drilling site was normalized by the share/fraction of monthly/seasonal precipitation in annual total at the referenced station. To verify the core chronology in the Altai ice core, we used the marker horizon of the Pinatubo (Philippines) volcanic 


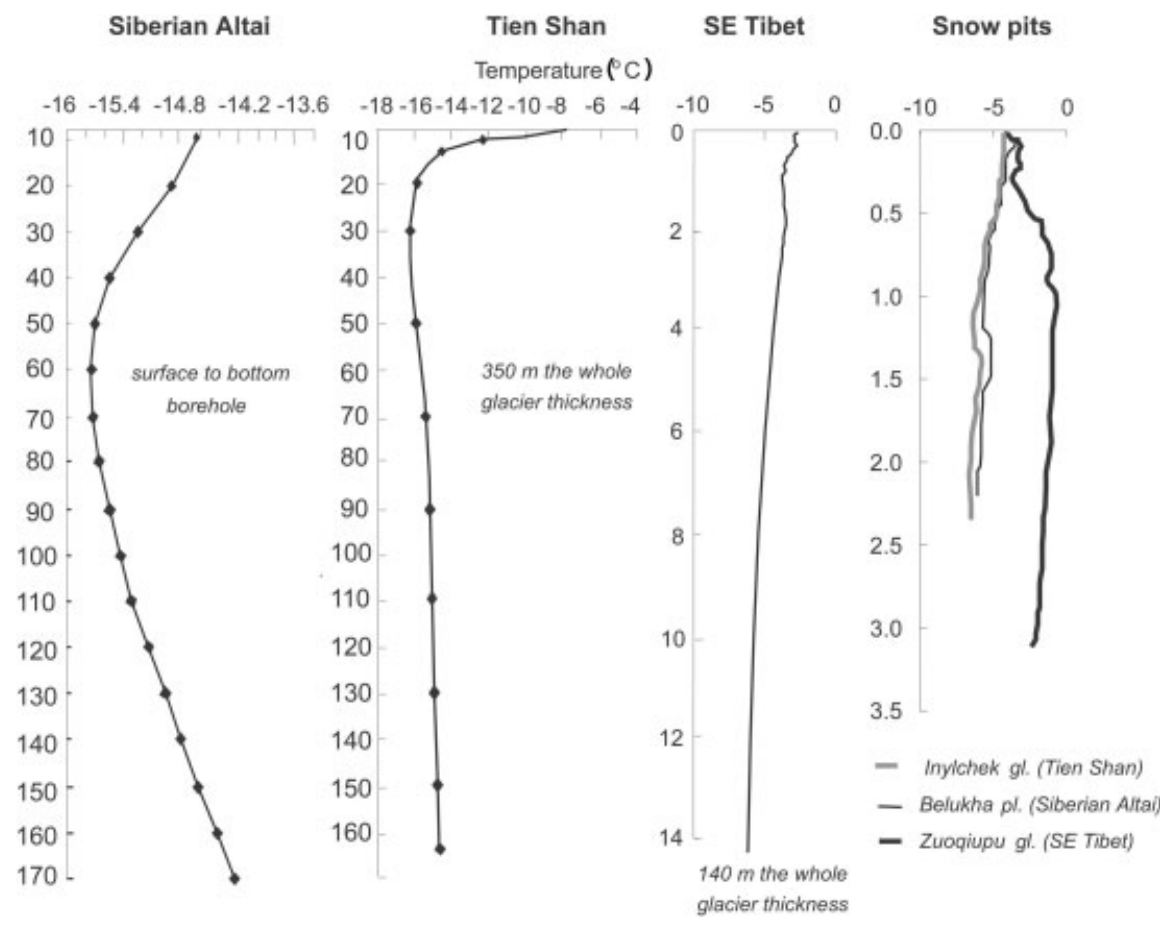

Fig. 4. Borehole temperature profiles and snow-pit temperatures.

eruption (June 2001). The ice layers of volcanic origin have been deduced from acidity measurements along firn/ice cores (Zielinski and others, 1996). The sulfate peak measured in the ice core is related to the firn-core layer of MayJune 1991, corresponding to the Pinatubo eruption with monthly precision.

Calculated seasonal snow accumulation layers were differentiated by crystal structure and were identified by the presence of yellow-brown aeolian dust. Uncertainty in calculating seasonal accumulation using the normalization technique was less than $\pm 10 \%$ of the seasonal accumulation rate obtained from the snow/firn-core stratigraphic profile. Snow/firn stratigraphic profiles allowed proportioning the firn-core layers at seasonal resolution, while monthly precipitation data from the closest meteorological stations detailed the firn-core records with monthly resolution for spring, summer and autumn. The thin winter layers were considered as the sum of accumulation for 3 months.

Table 3. Clustered average/extreme $\delta^{18} \mathrm{O}$ and $\mathrm{d}$-excess values from accumulation layers formed by precipitation originating from central Asian (CA) and oceanic moisture sources and their share in the total annual and seasonal accumulation layers. SP is prevailing synoptic pattern

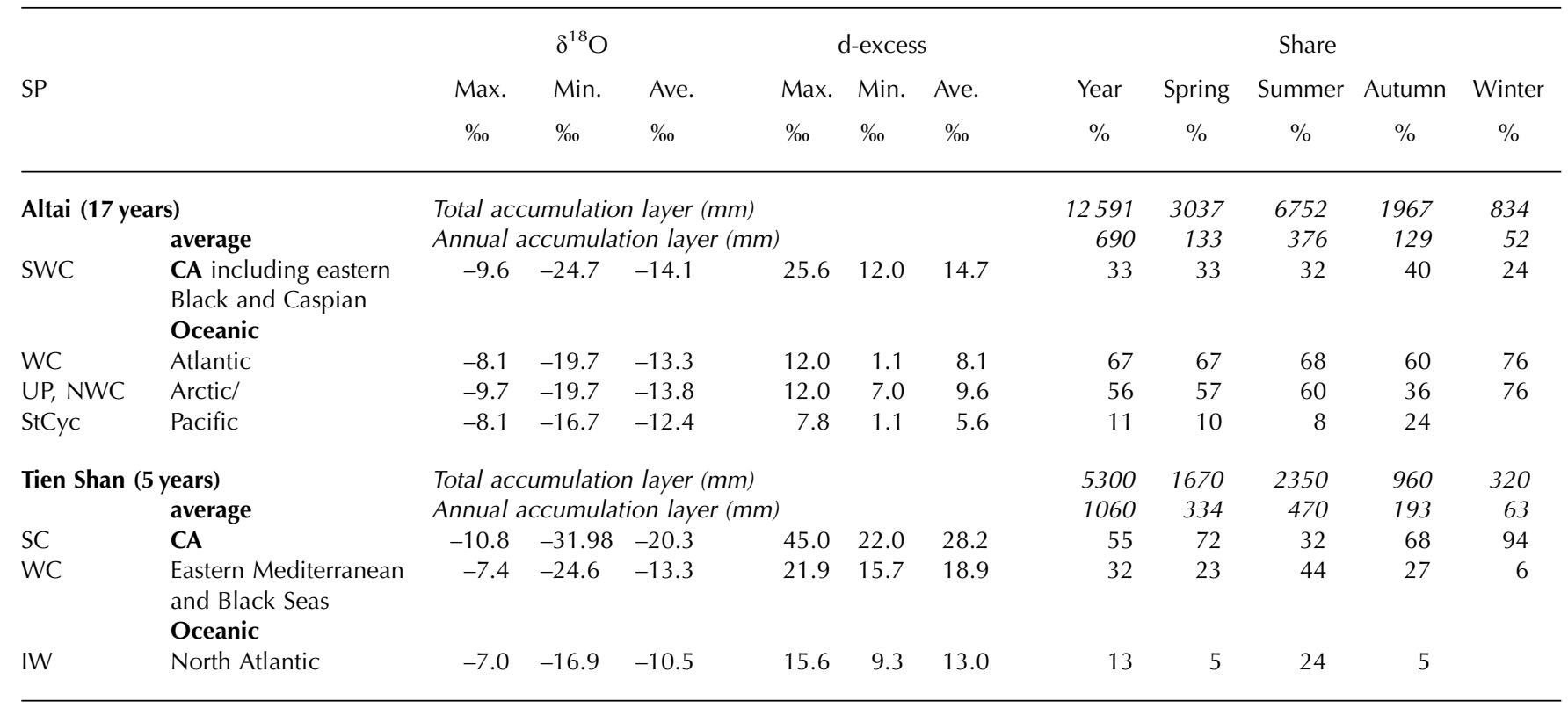

Notes: Altai: SWC is southwestern cyclones; WC is western cyclones; UP is ultra-polar intrusions; NWC is northwestern cyclones; StCyc is stationary cyclones. Tien Shan: SC is southern cyclones including south Caspian, Murgab and Upper Amy Darya' cyclones; WC is western cyclones; IW is influxes of air masses from west. 

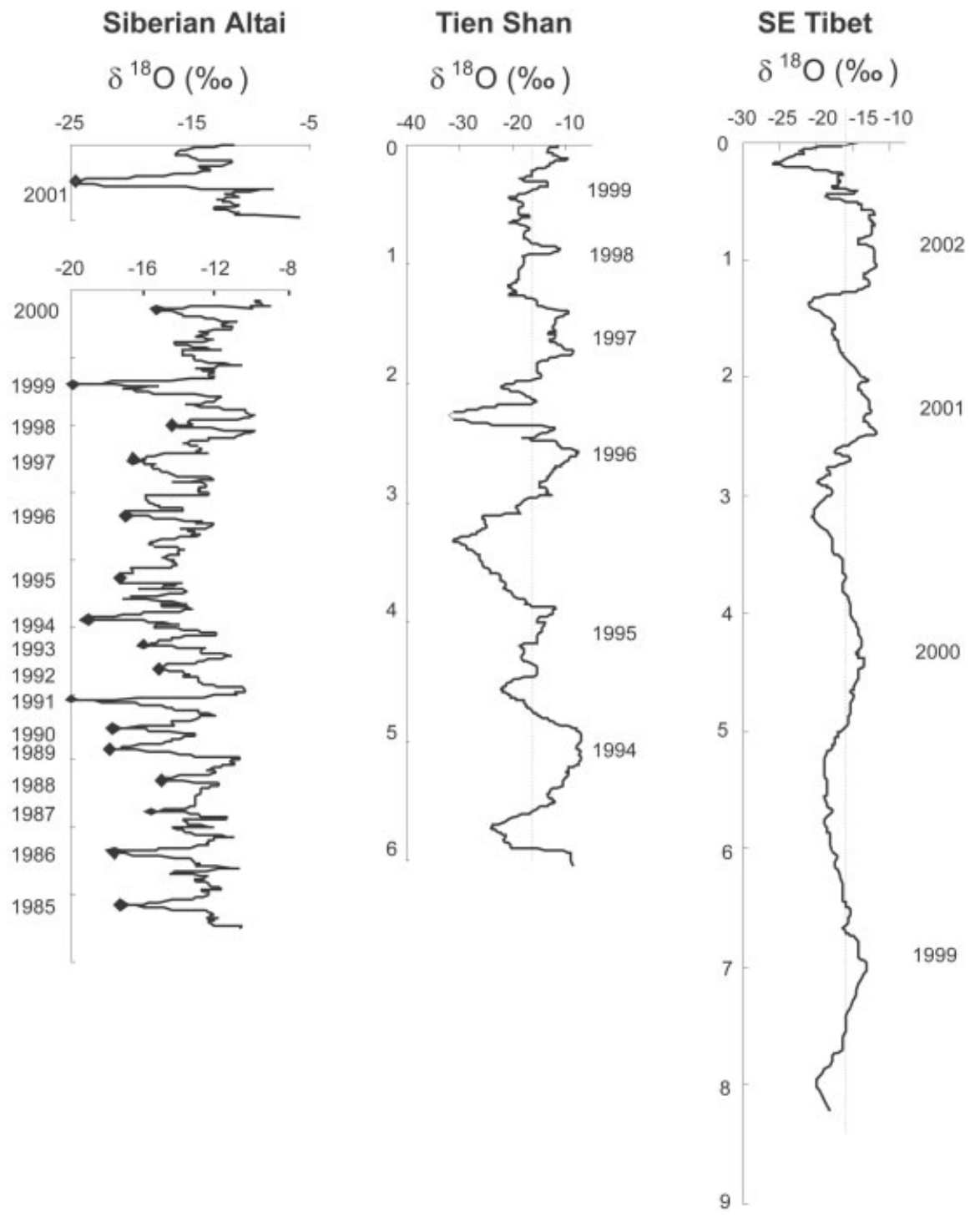

Fig. 5. Isotopic composition, $\delta^{18} \mathrm{O}$ in snow/firn cores.

To evaluate the links between isotope/geochemical records in the firn-core profile and synoptic pattern prevalence, we calibrated the measured isotope values in snow-pit layers to corresponding dates of the observed prevailing synoptic pattern. The automatic daily measurements of surface level changes provide daily information on snow accumulation at the Altai drilling site during 2 months, enabling calibration of the isotope/geochemistry records in snow pits at event scale, with a standard error of $7.5 \mathrm{~mm}$ (Aizen and others, 2005).

Monthly snow accumulation values for 2000, calculated by the normalization technique, agreed with corresponding values calculated using the event snow surface changes. The normalization techniques at the Tien Shan drilling site were validated through precipitation events at the Tien Shan station and corresponding accumulation layers in the snow-pit stratigraphy (Fig. 3c; Aizen and others, 2004).

\subsection{Clustering precipitation transferred from oceanic and central Asian moisture sources}

To distinguish oceanic moisture from water vapor reevaporated from internal basins and transferred to the high/middle latitudes of Asia, the $\delta^{18} \mathrm{O}$ isotopic ratio and d-excess values from 524 samples from the Altai and 264 samples from the Tien Shan cores were clustered into two distinct datasets. The clustering procedure was based on the $K$-means clustering analysis of splitting a set of data into two groups by maximizing between-cluster variation relative to within-cluster variation (Table 3).

To evaluate the link between stable-isotope concentrations in the firn-core profile and atmospheric circulation dynamics, we matched the measured ${ }^{18} \mathrm{O}$ and d-excess values in snow-pit layers to corresponding precipitation events observed at the meteorological stations. The snow accumulation event values in the snow pit were calculated using a normalization technique (see section 4.1). The ${ }^{18} \mathrm{O}$ values and $d$-excess mean in snow layers during precipitation events were related to the synoptic patterns of associated precipitation (Aizen and others, 2004, 2005). Analysis of synoptic processes prevailing during precipitation events over west Siberia and central Asia is in accordance with results from the $K$-means clustering analysis, with about a $15 \%$ deviation, i.e. the accumulation where the stable-isotope distribution was not in accordance with developed clustering amounted to $929 \mathrm{~mm}$ of the total 

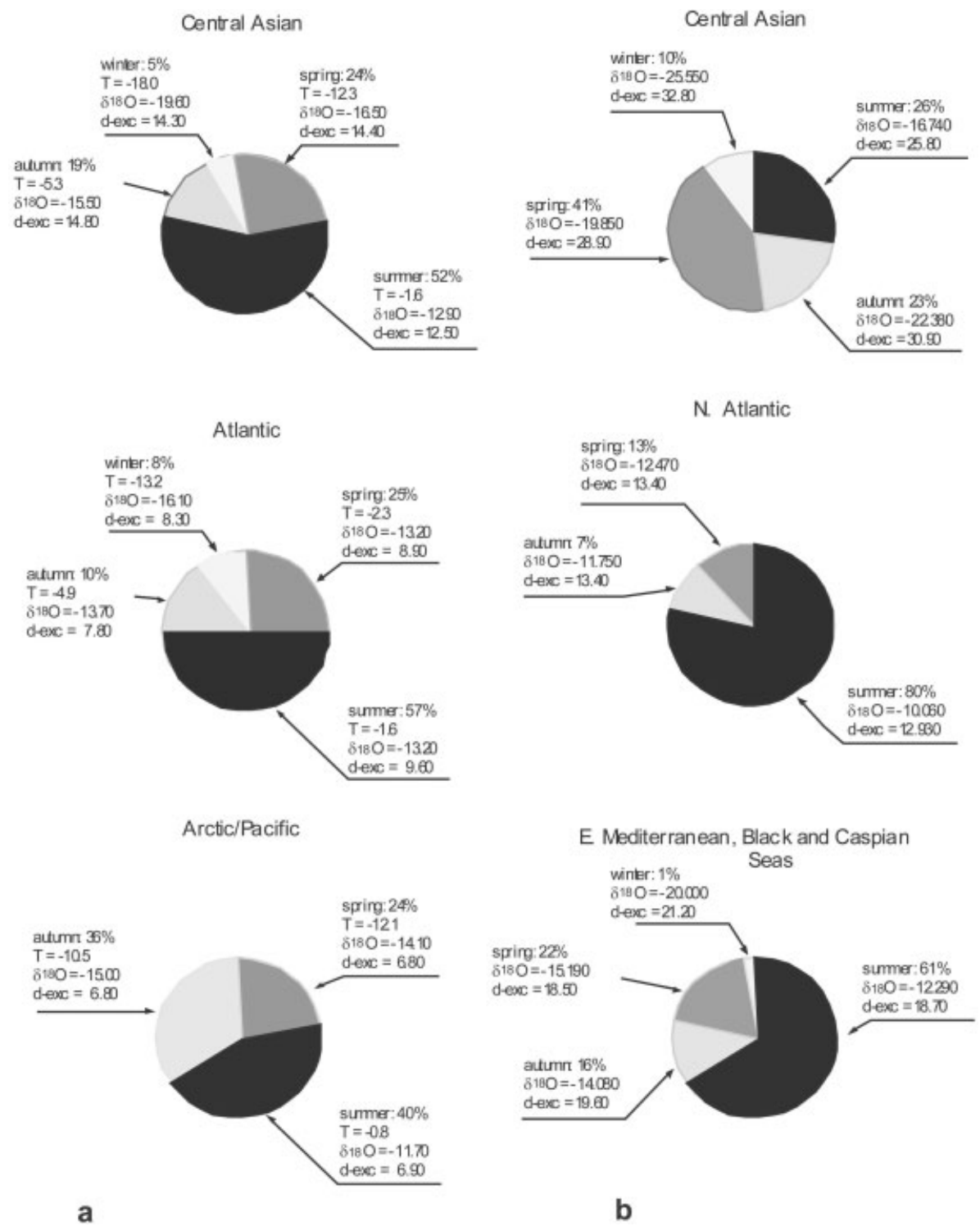

Fig. 6. Seasonal contributions to mean annual Altai (a) and Tien Shan (b) accumulation of precipitation originating from external and internal moisture sources: share; average oxygen and deuterium excess.

Altai accumulation of $12591 \mathrm{~mm}$. The main uncertainty occurred during winter months when several insignificant precipitation events with both oceanic and inter-land moisture sources were associated with the same snow accumulation layer.

\section{CONTRIBUTION OF OCEANIC AND CENTRAL ASIAN MOISTURE SOURCES}

\subsection{Clusters}

The revealed clusters for Altai ice-core records are: oceanic sources with d-excess less than $12 \%$ and the Aral-Caspian closed-drainage-basin sources with d-excess exceeding $12 \%$ (up to $25.6 \%$ ). Oceanic source is differentiated from Atlantic moisture source with d-excess ranging from $7.0 \%$ to $12 \%$. Moisture of Arctic and Pacific origin is associated with the lowest $\mathrm{d}$-excess levels $(<7.8 \%$ ) $)$. The main synoptic pattern that brings moisture to the Siberian Altai is the western cyclones pattern from the Atlantic Ocean. Strong depletion in $\delta^{18} \mathrm{O}$ and in $\mathrm{d}$-excess records is associated with synoptic patterns of northwestern and ultra-polar cyclones that bring moisture from the Arctic Ocean. Increased development of stationary cyclones is associated with $\delta^{18} \mathrm{O}$ enrichment and d-excess depletion. High d-excess values are associated with precipitation carried by southwestern cyclones and are a result of re-evaporating water vapor from the internal Aral-Caspian basin.

The revealed clusters for Tien Shan ice-core records are: recycled precipitation has the highest d-excess values, of 15.6-45\%; re-evaporated precipitation originating over the Aral-Caspian basin and brought by southern cyclones has d-excess $>22.0 \%$; and precipitation re-evaporated over the eastern Mediterranean and Black Seas has records with $15.6 \%$ o d-excess $<22.0 \%$ values. The western influxes from the North Atlantic bring precipitation with low $\mathrm{d}$-excess values of $9-16 \%$. Most enriched $\delta^{18} \mathrm{O}$ snow accumulation layers of $-7.0 \%$ are typical during domination of this synoptic mode. Contributions of precipitation originating from external and internal moisture sources to mean annual/seasonal accumulation at the Altai and Tien Shan locations were estimated through the developed clustering (Table 3). 

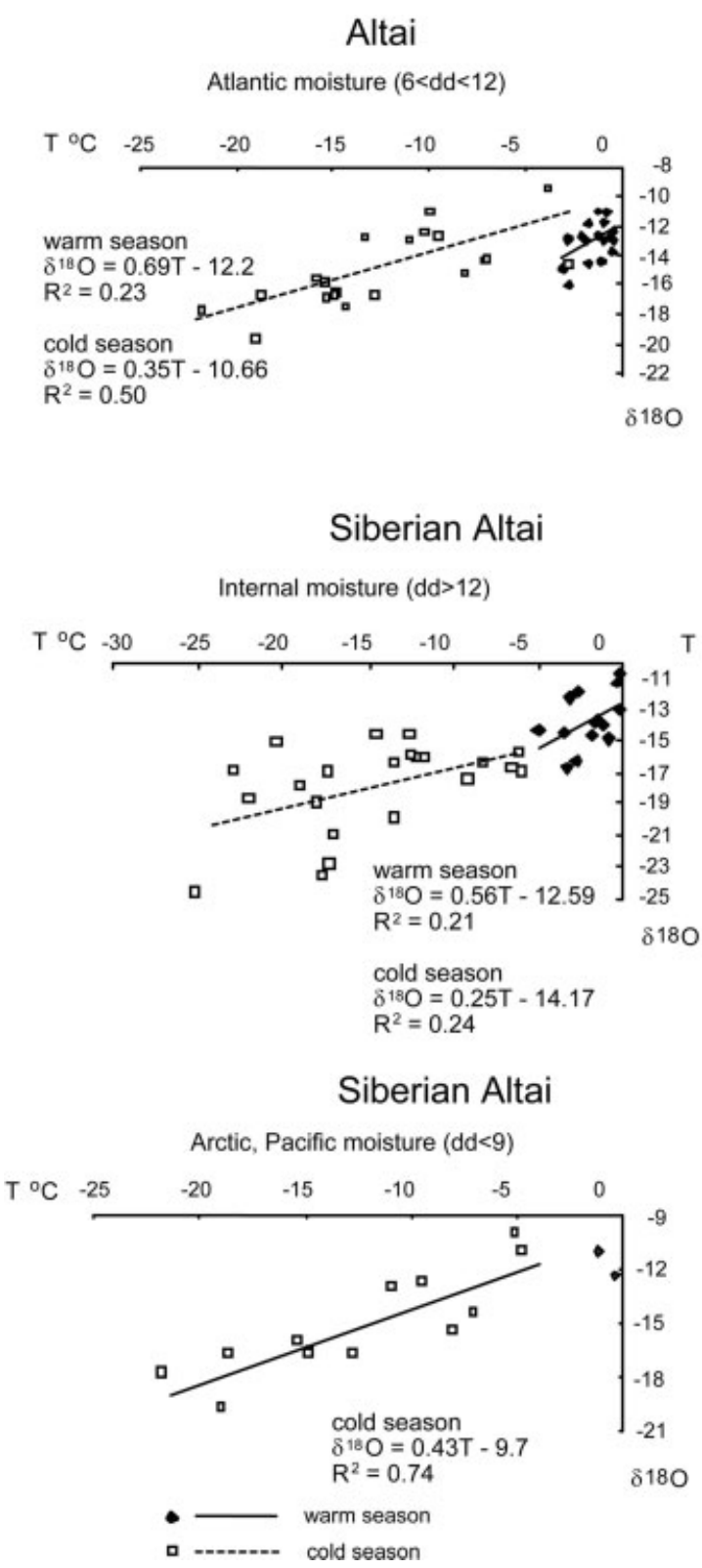

Tien Shan

North Atlantic

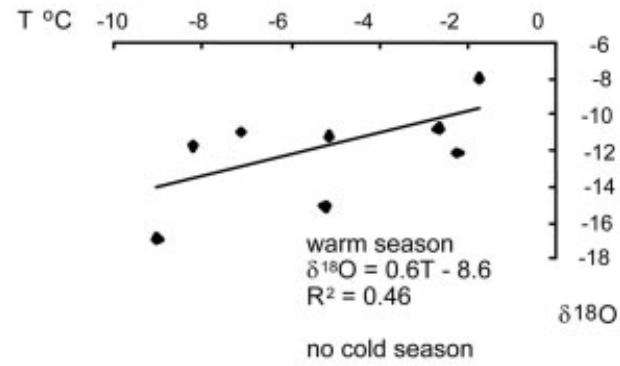

Tien Shan

Internal moisture (CA and E. Mediterranean/Black Seas)

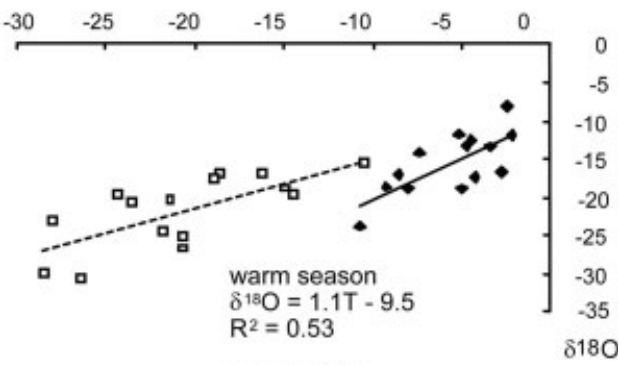

cold season

$\delta^{18} \mathrm{O}=0.7 \mathrm{~T}-8.2$

$\mathrm{R}^{2}=0.53$

\section{Southeastern Tibet}

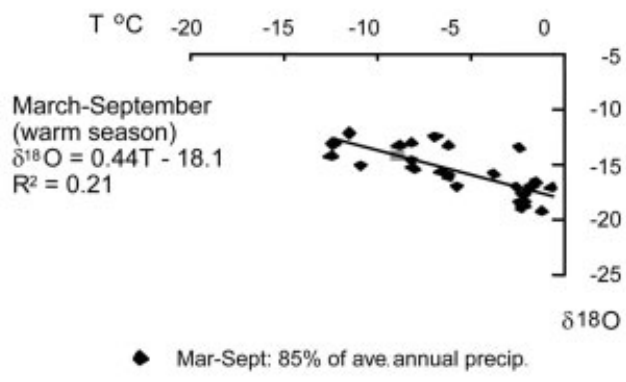

Fig. 7. Oxygen air-temperature regression $\left(\delta^{18} \mathrm{O} / T\right)$, with positive slopes for the Siberian Altai (a) and Tien Shan (b) and negative slopes for the Bomi (c) ice-core records.

\subsection{Altai accumulation}

The largest share $(67 \%)$ of total snow/firn accumulation corresponds to precipitation transferred by western, northwestern, stationary cyclones and ultra-polar intrusions from oceanic moisture sources (Table 3). Precipitation over the Siberian Altai is mainly marine in origin during all seasons, with the oceanic share almost invariable, ranging from $76 \%$ in winter to $60 \%$ in autumn accumulation. Moisture evaporated over the Atlantic Ocean comprises more than half of the annual accumulation (56\%). Precipitation transferred from the Arctic Ocean or an eastern moisture source, with the lowest d-excess levels, comprises $11 \%$ of the annual accumulation, with autumn maximum (24\%) and summer minimum ( $8 \%$ ). The remaining 34\% corresponds to precipitation transferred by southwest cyclones and recycled over internal moisture sources, with the largest share (40\%) occurring in autumn. The smallest share of recycled precipitation (24\%) transferred from internal moisture sources to the Altai glaciers was observed in winter, when the Siberian High is strongest, blocking any intrusion of air masses, and conditions for inland evaporation and local convection are weakest because of low continental heating.

Summer is the main season of accumulation, i.e. both from external and internal moisture sources (Fig. 6). The Atlantic moisture as well as recycled moisture over central Asia was brought to the Siberian Altai year-round. From autumn to spring, $\delta^{18} \mathrm{O}$ records associated with inter-land moisture sources are more depleted than $\delta^{18} \mathrm{O}$ records related to Atlantic moisture sources because of lower air temperatures over the continent than over the ocean. Summer mean isotope records are almost the same. The mean values of $\delta^{18} \mathrm{O}$ from summer accumulation layers with Arctic/eastern-originated precipitation sources are the most enriched among the three considered clusters, reaching $-11.7 \%$. The highest $\delta^{18} \mathrm{O}$ values may be associated with the highest air temperature during precipitation and/or nearby water-vapor formation (e.g. Arctic/Pacific Ocean or local summer convection). 


\subsection{Tien Shan accumulation}

Central Asia receives most of its moisture from the west, and its interiors are heavily dependent upon the intensity of zonal water-vapor transport. Influxes of air masses from the west are one of the main synoptic modes in the central Tien Shan, and these air masses bring $13 \%$ of marine-derived precipitation from the North Atlantic Ocean, with the highest annual values of $\delta^{18} \mathrm{O}$ and the most depleted $\mathrm{d}$ excess means. The percentage of summer moisture from the North Atlantic reached $24 \%$ of total summer mean (Table 3 ).

Western cyclones originating over the eastern Mediterranean and Black Seas brought more significant precipitation to the central Tien Shan, comprising up to $32 \%$ of annual precipitation and reaching $44 \%$ during summer. Because of very hot summers, the precipitated water in central Asia is recycled several times inside the Aral-Caspian closed drainage basin and is even transported to the Arctic basin (see section 5.1). The maximum contribution to central Tien Shan accumulation is associated with recycled moisture (up to $87 \%$ ) including $55 \%$ from the Aral-Caspian and $32 \%$ from the eastern Mediterranean and Black Seas. During spring, the maximum contribution occurred due to recycled moisture from central Asia, reaching $72 \%$, because warming of the inner continental regions occurs faster than in the coastal regions, increasing inland evaporation. During winter, all of central Asia is blocked by the Siberian high. The minimal winter precipitation mainly originated over central Asia (up to $94 \%$ ), with the highest d-excess values (maximum up to $45 \%$ ) (Table 3 ).

Summer is the main season of accumulation, as at the Altai location (Fig. 6), reaching $80 \%$ in North Atlanticoriginated precipitation. There are no records with low dexcess values (North Atlantic) in accumulation layers related to winter months, while recycled moisture over central Asia was brought to the central Tien Shan year-round.

\section{STABLE-ISOTOPE-AIR-TEMPERATURE RELATIONSHIP}

Local isotope-temperature relationships were calibrated using the seasonal air temperatures and prevailing atmospheric circulation pattern. The Altai and Tien Shan ice-core records of oxygen isotopic ratios and d-excess, clustered according to moisture origin (see section 5.1; Table 3) and differentiated with monthly resolution (see section 4.1), were related to the corresponding monthly air temperature (Fig. 7), which was linearly extrapolated to the drilling sites (see section 2.1).

Transfer function slopes (for the Tien Shan and Altai) and intercept (for Altai) for warm-season Atlantic moisture (Fig. 7) are similar to the $\delta^{18} \mathrm{O}-T$ relationship $\left(\delta^{18} \mathrm{O}=\right.$ $0.69 T-13.6)$ found by Dansgaard (1964) for North Atlantic precipitation.

The core data from the mountain systems with continental climate features exhibit positive regression-line slopes, with more depleted precipitation occurring during the coldest winter temperatures. Shallower regression-line slopes (0.69-0.35) are present for the Altai core record (Fig. 7) compared to regression-line slopes (1.1-0.6) for the Tien Shan record. These differences relate to varying amounts of precipitation, moisture source regions, as well as differing temperature regimes (Fig. 2). The Altai raw-data histogram shows lower frequency of depleted accumulation

\section{Siberian Altai}

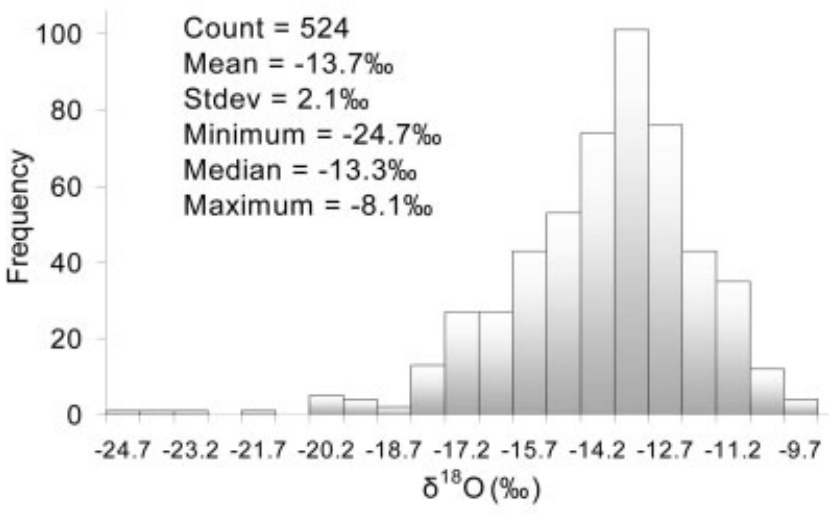

Tien Shan

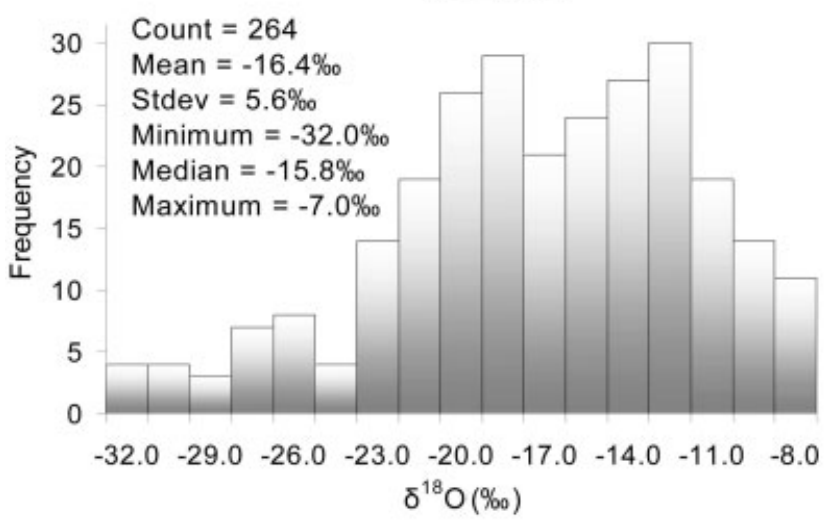

Southeastern Tibet

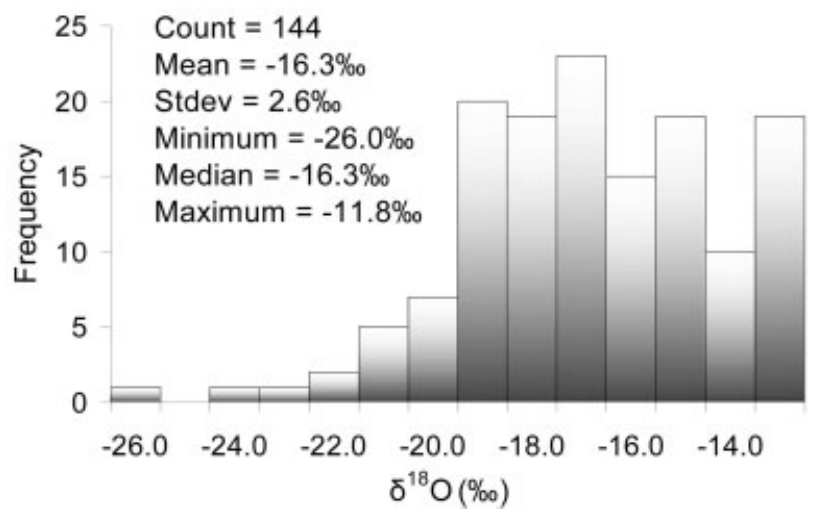

Fig. 8. $\delta^{18} \mathrm{O}(\%)$ data description and basic statistics of records from the Belukha plateau (4115 m; 1984-2001), Inilchek glacier, (5200 m; 1991-98) and the Bomi glaciation (5795 m; 1998-2001).

than Tien Shan, which is associated with minimal coldseason precipitation at the Altai study site (Fig. 8). The highest positive slopes are associated with internal moisture, possibly due to low inter-land humidity during evaporation and quicker processes of isotope depletion. The maximum slope is typical for the Inilchek summer accumulation formed by precipitation from internal moisture sources.

Glacier accumulation regions with marine climates are distinguished by a lowering of the slope, with negative regression-line slopes typical for southern periphery monsoon regions. The southeast Tibetan firn-core isotope data were examined for the months with most precipitation (March-September), producing isotope-air-temperature 
Table 4. Linear trends $(\beta)$ of monthly precipitation and air temperature at the Akkem station obtained from Siberian Altai ice core and corresponding long-term monthly climatic variables for the period 1984-2001. Bold font corresponds to statistically significant linear trend at $10 \%$

\begin{tabular}{|c|c|c|c|c|c|c|c|c|c|c|c|c|c|}
\hline & Jan & Feb & Mar & Apr & May & Jun & Jul & Aug & Sep & Oct & Nov & Dec & Year \\
\hline \multicolumn{14}{|c|}{ Precipitation } \\
\hline$\beta\left(\mathrm{a}^{-1}\right)$ & 0.45 & 0.52 & 0.53 & 0.20 & -0.01 & 0.02 & 0.01 & 0.02 & 0.04 & 0.03 & -0.11 & 0.10 & 0.03 \\
\hline$\sigma_{\beta}$ & 0.32 & 0.31 & 0.21 & 0.05 & 0.06 & 0.04 & 0.05 & 0.07 & 0.07 & 0.07 & 0.17 & 0.26 & 0.02 \\
\hline$r^{2}$ & 0.11 & 0.14 & 0.28 & 0.45 & 0.00 & 0.01 & 0.00 & 0.01 & 0.02 & 0.01 & 0.02 & 0.01 & 0.13 \\
\hline$F$ & 2.04 & 2.69 & 6.58 & 13.69 & 0.01 & 0.26 & 0.06 & 0.12 & 0.31 & 0.18 & 0.43 & 0.15 & 2.56 \\
\hline \multicolumn{14}{|c|}{ Air temperature } \\
\hline$\beta\left(\mathrm{a}^{-1}\right)$ & -0.23 & 1.30 & 0.77 & 0.92 & 1.81 & 3.24 & 3.22 & 3.94 & 0.62 & 0.71 & 0.47 & 0.00 & 4.17 \\
\hline$\sigma_{\beta}$ & 0.49 & 0.39 & 0.45 & 0.63 & 0.67 & 0.77 & 1.32 & 1.09 & 0.62 & 0.46 & 0.42 & 0.48 & 0.98 \\
\hline$r^{2}$ & 0.01 & 0.40 & 0.15 & 0.11 & 0.30 & 0.51 & 0.26 & 0.43 & 0.06 & 0.12 & 0.07 & 0.00 & 0.52 \\
\hline$F$ & 0.23 & 11.35 & 2.93 & 2.14 & 7.24 & 17.85 & 5.97 & 13.03 & 1.02 & 2.36 & 1.23 & 0.00 & 18.15 \\
\hline
\end{tabular}

Note: $\sigma_{\beta}$ is standard error value for slope coefficient; $r^{2}$ is coefficient of determination; $F$ is $F$ statistic.

relationships with slopes of -0.44 . Negative regression-line slopes (Fig. 7) are associated with heavy amounts of depleted moisture arriving during periods of maximum precipitation (March-September) and warmest annual average temperatures. This opposite seasonal relationship of isotopic records has been previously observed at subtropical ice-core locations by Qin and others (2002) and Thompson and others (2003), as well as from isotopic records of precipitation from southeast Asia (Araguás-Araguás and others, 1998).

\section{VARIABILITY IN THE ALTAI ICE-CORE RECORDS}

To analyze the ability of ice-core records to represent the climatic and atmospheric dynamic changes, linear trends, standard errors, coefficients of determination and $F$ tests were calculated. Estimations were based on monthly means of isotope, geochemistry and dust-particle data obtained from Altai ice-core records for 17 years (Tables 4 and 5). Verification of the obtained trends occurred through longterm monthly climatic and synoptic data for the corresponding period. Linear trends for climatic variables (air temperatures and precipitation) were calculated for the period 1984-2001. During this time, we found statistically significant increases in precipitation in March and April, and in air temperature in February, May, June, July and August (Table 4). However, stable-isotope records of $\delta^{18} \mathrm{O}$ reflecting the air-temperature variability did not show a trend for the considered period of years (Table 5).

The $d$-excess records from the Altai ice core (Table 5) show a negative trend for the period 1984-2001 ( $n \beta=$ $524(-0.0015)=-0.8 \%)$. Deuterium excess is a parameter reflecting re-evaporation at land surfaces and/or mixing along air-mass trajectories (Merlivat and Jouzel, 1979). The decreasing d-excess values from 1984 on were probably caused by a changing source of moisture (e.g. by decreasing the share of re-evaporated precipitation or increasing the share of oceanic moisture (e.g. Atlantic/Arctic/easternoriginated precipitation)). Furthermore, decreased volume and concentration of dust particles (with sizes $>1.00 \mu \mathrm{m}$ ) and increased content of marine-originated ions of sodium and chloride also verified the weakening of central Asian reevaporated precipitation in the Altai. There was also the tendency of positive trends (not statistically significant) in frequency of northwestern cyclones (Table 5), which brought
Atlantic moisture to the Altai. At the same time there was a tendency for decreasing frequency of synoptic patterns that brought moisture as well as dust particles from central Asia, i.e. southwestern cyclones.

\section{CONCLUSION}

The technique of coupling synoptic climatology and meteorological data with $\delta^{18} \mathrm{O}$ and d-excess in firn-core records was implemented to determine climate-related signals and to identify the origin of moisture. The firn-core records were calibrated at event scale and validated using the monthly meteorological data with $15 \%$ uncertainty. The method is applicable to reconstruct the climatic and atmospheric circulation dynamics over past centuries from surface-to-bottom deep ice cores recovered from the Belukha firn plateau and Inilchek glacier. The clusters in $\delta^{18} \mathrm{O}$ and d-excess records in the Altai and Tien Shan firn/ice cores revealed that the precipitation is oceanic in origin and recycled moisture from the Aral-Caspian closed drainage basin.

Two-thirds of the Altai accumulation is formed from oceanic precipitation for the period 1984-2001; the rest of the precipitation is recycled over Aral-Caspian sources. More than half of the accumulation has an Atlantic Ocean origin, and precipitation from the Arctic and Pacific Oceans contributed about $11 \%$. The inter-land moisture sources contributed the remaining 33\% of annual Altai precipitation. The recycled annual amount of Tien Shan accumulation reached up to $87 \%$ of the total, with the highest d-excess values. Precipitation recycled from the Aral-Caspian basin contributed 55\%, and the Mediterranean and Black Seas about $30 \%$, to the Tien Shan mean annual accumulation. Only $13 \%$ of annual snow accumulation, with low d-excess and most enriched $\delta^{18} \mathrm{O}$ values, is brought from the North Atlantic. However, from 1984 to 2001, there is a tendency of decreasing d-excess values in Altai ice-core records that is in accordance with the decreasing dust content in corresponding ice-core layers and the strengthening of synoptic patterns that brought the precipitation of Atlantic origin.

The ice-core data from the mountain systems with continental climate features exhibit positive regression-line slopes in isotope-air-temperature annual-seasonal relationships, with a shallower slope for the Altai compared to the 
Table 5. Linear trends $(\beta)$ of isotope and geochemistry records at the Akkem station obtained from Siberian Altai ice core for the period 1984-2001. Bold font corresponds to statistically significant linear trend at $10 \%$

\begin{tabular}{|c|c|c|c|c|c|c|c|c|c|c|c|c|}
\hline & \multirow{3}{*}{$\begin{array}{c}P \\
\mathrm{~mm}\end{array}$} & \multirow{3}{*}{$\begin{array}{l}T \\
{ }^{\circ} \mathrm{C}\end{array}$} & \multicolumn{2}{|c|}{ Isotope } & \multicolumn{3}{|c|}{ Dust particles number } & \multicolumn{3}{|c|}{ Major ions } & \multicolumn{2}{|c|}{ SP } \\
\hline & & & $\delta^{18} \mathrm{O}$ & d-excess & Total & $4.00-5.04 \mu \mathrm{m}$ & Volume & $\mathrm{Cl}^{-}$ & $\mathrm{Na}^{+}$ & $\mathrm{Ka}^{+}$ & NWC & SWC \\
\hline & & & $\%$ & $\%$ & $\mathrm{~mL}^{-1}$ & $\mathrm{~mL}^{-1}$ & $\mathrm{ppb}$ & $\mathrm{ppb}$ & $\mathrm{ppb}$ & $\mathrm{ppb}$ & days & days \\
\hline$\beta\left(\right.$ record $\left.^{-1}\right)$ & 0.35 & 0.007 & 0.002 & -0.0015 & 0.0001 & -0.02 & 0.0001 & 0.25 & 0.55 & 0.59 & 0.09 & -0.06 \\
\hline$\sigma_{\beta}$ & 0.004 & 0.001 & 0.005 & 0.0012 & 0.0001 & 0.006 & 0.0000 & 0.1 & 0.13 & 0.29 & 0.016 & 0.09 \\
\hline$r^{2}$ & 0.004 & 0.001 & 0.0003 & 0.0056 & 0.0087 & 0.081 & 0.06 & 0.029 & 0.08 & 0.12 & 0.006 & 0.02 \\
\hline$F$ & 0.93 & 0.42 & 0.1463 & $3 \quad 2.9$ & 1.73 & 17.34 & 12.02 & 5.95 & 17.59 & 27.52 & 1.12 & 0.83 \\
\hline$n$ & 217 & 217 & 524 & 524 & 199 & 199 & 199 & 199 & 199 & 199 & 204 & 204 \\
\hline
\end{tabular}

Note: $P$ and $T$ are monthly annual precipitation and air temperatures respectively; SP is frequency of synoptic patterns; $\sigma_{\beta}$ is standard error value for slope coefficient; $r^{2}$ is coefficient of determination; $F$ is $F$ statistic; $n$ is number of records; NWC and SWC are monthly frequency of northwestern and southwestern cyclone respectively.

Tien Shan records. Glacier accumulation regions with marine climate are distinguished by a lowering of the slopes so that the negative regression-line slopes are typical for southern periphery monsoon regions. Signs in regressionline slopes for the northern periphery of the Asian mountain system as well as for southeast Tibet are comparable with results of Araguas-Aráguás and others (1998) for Asia precipitation.

\section{ACKNOWLEDGEMENTS}

We acknowledge grants from the US National Science Foundation (ATM-9905670), the US Department of Energy (DE-A107) and the US National Geographic Society, which made this research possible. We are grateful to M.E. Davis for valuable comments and editorial work.

\section{REFERENCES}

Aizen, V.B. and E.M. Aizen. 1997. Hydrological cycles on the north and south peripheries of mountain glacial basins of central Asia. Hydrol. Process., 11(5), 451-469.

Aizen, V., E. Aizen, J. Melack and T. Martma. 1996. Isotopic measurements of precipitation on central Asian glaciers (southeastern Tibet, northern Himalayas, central Tien Shan). J. Geophys. Res., 101(D4), 9185-9196.

Aizen, V.B., E.M. Aizen, J.M. Melack, K.J. Kreutz and L.D. Cecil. 2004. Association between atmospheric circulation patterns and firn-ice core records from the Inilchek glacierized area, central Tien Shan. J. Geophys. Res., 109(D8), D08304. (10.1029/ 2003JD003894.)

Aizen, V.B., E. Aizen, K. Fujita, S.A. Nikitin, K.J. Kreutz and N. Takeuchi. 2005. Stable-isotope time series and precipitation origin from firn cores and snow samples, Altai glaciers, Siberia. J. Glaciol., 51(175), 637-654.

Araguás-Araguás, L., K. Froelich and K. Rozanski. 1998. Stable isotope composition of precipitation over southeast Asia. J. Geophys. Res., 103(D22), 28,721-28,742.

Barlow, L.K., J.W.C. White, R.G. Barry, J.C. Rogers and P. Grootes. 1993. The North Atlantic oscillation signature in deuterium and deuterium excess signals in the Greenland Ice Sheet Project 2 ice core, 1840-1970. Geophys. Res. Lett., 20(24), 2901-2904.

Basile, I., F.E. Grousset, M. Revel, J.R. Petit, P.E. Biscaye and N.I. Barkov. 1997. Patagonian origin of glacial dust deposited in East Antarctica (Vostok and Dome C) during glacial stages 2, 4 and 6. Earth Planet Sci. Lett., 146(3-4), 573-589.
Biscaye, P.E. and 6 others. 1997. Asian provenance of glacial dust (stage 2) in the Greenland Ice Sheet Project 2 ice core, Summit, Greenland. J. Geophys. Res., 102(C12), 26,765-26,781.

Bugaev, V.A. and 6 others. 1957. Sinopticheskie processi nad Srednei Aziey [Synoptic processes of central Asia]. Tashkent, Uzbeck SSR Academy of Science Publishing.

Dansgaard, W. 1964. Stable isotopes in precipitation. Tellus, 16(4), 436-468.

Jouzel, J. and 12 others. 1997. Validity of the temperature reconstruction from water isotopes in ice cores. J. Geophys. Res., 102(C12), 26,471-26,487.

Kang, S., C.P. Wake, D. Qin, P.A. Mayewski and T. Yao. 2000. Monsoon and dust signals recorded in Dasuopu glacier, Tibetan Plateau. J. Glaciol., 46(153), 222-226.

Kreutz, K.J., V.B. Aizen, L.D. Cecil and C.P. Wake. 2001. Oxygen isotopic and soluble ionic composition of a shallow firn core, Inilchek glacier, central Tien Shan. J. Glaciol., 47(159), 548-554.

Kreutz, K.J., C.P. Wake, V.B. Aizen, L.D. Cecil and H.A. Synal. 2003. Seasonal deuterium excess in a Tien Shan ice core: influence of moisture transport and recycling in Central Asia. Geophys. Res. Lett., 30(18), 1922. (10.1029/2003GL017896.)

Mayewski, P.A. and 13 others. 1994. Changes in atmospheric circulation and ocean ice cover over the North Atlantic during the last 41,000 years. Science, 263(5154), 1747-1751.

Mayewski, P.A. and 6 others. 1997. Major features and forcing of high-latitude Northern Hemisphere atmospheric circulation using a 110,000-year-long glaciochemical series. J. Geophys. Res., 102(C12), 26,345-26,366.

Merlivat, L. and J. Jouzel. 1979. Global climatic interpretation of the deuterium-oxygen 18 relationship for precipitation. J. Geophys. Res., 84(C8), 5029-5033.

Narojniy, U.K., O.V. Narojnaya and K.I. Popova. 1993. Cyrculacionniy regime $\mathrm{i}$ gidrotermicheskie usloviya zim Altaya [The atmospheric circulation regime and hydro-thermal winter conditions in Altai]. Glaciologiya Altaya, 4(19), 183-188.

O'Brien, S.R., P.A. Mayewski, L.D. Meeker, D.A. Meese, M.S. Twickler and S.I. Whitlow. 1995. Complexity of Holocene climate as reconstructed from a Greenland ice core. Science, 270(5244), 1962-1964.

Olivier, S. and 10 others. 2003. Glaciochemical investigation of an ice core from Belukha Glacier, Siberian Altai. Geophys. Res. Lett., 30(19), 2019. (10.1029/2003GL018290.)

Petit, J.R. and 18 others. 1999. Climate and atmospheric history of the past 420,000 years from the Vostok ice core, Antarctica. Nature, 399(6735), 429-436.

Popova, K.I. 1972. O tipah godovogo hoda atmosphernich osadkov $\checkmark$ Gornom Altae [About the type of annual precipitation distribution in Altai mountains]. Glaciologiya Altaya, 7, 169-174. 
Qin, D. and 9 others. 2000. Evidence for recent climate change from ice cores in the central Himalaya. Ann. Glaciol., 31, 153-158.

Qin, D. and 6 others. 2002. Preliminary results from the chemical records of an $80.4 \mathrm{~m}$ ice core recovered from East Rongbuk Glacier, Qomolangma (Mount Everest), Himalaya. Ann. Glaciol., 35, 278-284.

Shuman, C.A., R.B. Alley, S. Anandakrishnan, J.W.C. White, P.M. Grootes and C.R. Stearns. 1995. Temperature and accumulation at the Greenland Summit: comparison of high-resolution isotope profiles and satellite passive microwave brightness temperature trends. J. Geophys. Res., 100(D5), 9165-9177.

Subbotina, O.I. 1995. Atmosfernaya circulaciaya [Atmospheric circulation]. In Muminova, F.A. and S.I. Inagamova, eds. Izmenenie Klimata $v$ Srednei Azii [Change of climate in middle Asia]. Tashkent, SARNIIGMI Publishing, 8-34.

Taylor, K.C. and 7 others. 1993. The 'flickering switch' of Late Pleistocene climate change. Nature, 361(6411), 432-436.

Thompson, L.G. and 9 others. 1989. Holocene-Late Pleistocene climatic ice core records from Qinghai-Tibetan Plateau. Science, 246(4929), 474-477.
Thompson, L.G. and 9 others. 1997. Tropical climate instability: the last glacial cycle from a Qinghai-Tibetan ice core. Science, 276(5320), 1821-1825.

Thompson, L.G., T. Yao, E. Mosley-Thompson, M.E. Davis, K.A. Henderson and P. Lin. 2000. A high-resolution millennial record of the south Asian monsoon from Himalayan ice cores. Science, 289(5486), 1916-1919.

Thompson, L.G., E. Mosley-Thompson, M.E. Davis, P.N. Lin, K. Henderson and T.A. Mashiotta. 2003. Tropical glacier and ice core evidence of climate change on annual to millennial time scales. Climatic Change, 59(1-2), 137-155.

Yao, T. and L.G. Thompson. 1992. Trends and features of climatic changes in the past 5000 years recorded by the Dunde ice core. Ann. Glaciol., 16, 21-24.

Yao, T., V. Masson, J. Jouzel, M. Stiévenard, W. Sun and K. Jiao. 1999. Relationship between $\delta^{18} \mathrm{O}$ in precipitation and surface air temperature in the Ürümqi river basin, east Tianshan mountains, China. Geophys. Res. Lett., 26(23), 3473-3476.

Zielinski, G.A., P.A. Mayewski, L.D. Meeker, S.I. Whitlow and M.S. Twickler. 1996. 110,000-yr record of explosive volcanism from the GISP2 (Greenland) ice core. Quat. Res., 45(2), 109-118. 